\title{
Kulturní animace - filosofická východiska a praktické využitíl
} Anna Dudová, Michal Kaplánek, Richard Macků

Jestliže Rada Evropy v roce 1978 doporučila členským státům rozvoj animace, měla na mysli jednoznačně animaci sociálně kulturní či sociální. ${ }^{2}$ Sociálně kulturní animaci mủžeme považovat za metodu sociální práce, která se realizuje nejvíce v rámci komunitní práce. Jejím východiskem je důvěra v kulturní potenciál, který je ukrył v té části populace, která je znevýhodněná a která bez této animace nemá často šanci svủj potenciál objevit, rozvinout a prosadit. ${ }^{3}$ Na první pohled jde tedy o radikálně demokratický, levicově orientovaný prístup. Takové chápání animace je na první pohled v prímém rozporu s myšlenkou tradiční výchovy, která je po staletí postavena na principu předávání hodnot, postojů a myšlenkových vzorců z generace na generaci, přičemž o tom, co „se má předávat" rozhoduje autorita (do doby osvícenství církev, resp. církve, později stát). ${ }^{4}$ Pokud bychom tedy v sociálně kulturní animaci hledali výchovné prvky, jednalo by se spiše o „empowerment" ve smyslu posilování emancipačních tendencí lidových vrstev a jejich schopnosti participace na politickém a sociálním rozvoji prostředí, v němž žijí.

Na pozadí takto chápané animace, která zažila svůj boom v 70. letech 20. století, mưžeme snadno pochopit, že „výchovné využiti“" animace, jak je navrhl začátkem 70. let mladý italský psycholog Mario Pollo, mnohým tehdejším sociálním aktivistưm připadalo jako zneužití ,,pokrokové myšlenky k reakčním účelưm“. Diskuse mezi tehdejšími italskými a francouzskými teoretiky animace se v některých bodech podobá současné české diskusi $\vee$ rámci sociální práce. Jedná se totiž o obdobné dilema: Do jaké míry má sociální pracovník, pedagog nebo jiný zástupce většinové společnosti ovlivňovat jednání těch, kteři se ocitli na jejím okraji, a do jaké míry musí respektovat jejich svobodu, a to i tehdy, když tito lidé škodí sobě i druhým? ${ }^{5}$ Pollovo pojetí animace proniklo skrze původně španělsky psané texty Juana Edmonda Vecchiho do povědomí pedagogické veřejnosti. ${ }^{6}$ Základem Pollova pojetí animace jsou antropologická východiska formulovaná v díle významných židovských a křestanských filosofů a psychologů 20. století. Navazuje na ně teologická interpretace situace současného člověka, kterou rozvinuli teologové prijímající Pollovo pojetí (Prieto, Tonelli, Vallabaraj). V animačním pojetí výchovy je stěžejním momentem osoba vychovatele - animátora. $V$ jeho pedagogických postojích a jednání mủžeme animaci rozpoznat. A pouze skrze prípravu animátorů také realizovat. Proto je klíčová část tohoto pojednání věnována profilu animátora a závěrečná část prípravě animátorů v salesiánském prostředí. Odraz myš-

\footnotetext{
1 Práce vznikla v rámci projektu specifického výzkumu GAJU 117/2013/H - Pojetí kvality sociální práce v souvislosti se sebedefinováním sociálního pracovníka a jeho pomáhající profese.

2 Jedná se o nejrozšířenější směr animace, který vychází z myšlenky společenské (sociální) kultury a označuje se jako sociokulturní, příp. sociálně kulturní nebo sociální animace. Doporučení Rady Evropy nese název Sociocultural Animation (Strassbourg: Council of Europe Council for Cultural Cooperation, 1978).

3 K tomuto tématu viz Michal KAPLÁNEK, Sociálně kulturní práce v lidových vrstvách, Caritas et veritas 2/2011, s. 30-37.

4 Nedostatek „partnerského př́stupu“ ve výchově a využívání, či dokonce zneužívání autority ze strany elit kritizoval jak Paulo Freire, tak i Hannah Arendtová a mnozí další.

5 Dilemata formulovaná Matissonem (Social Work, 2000) uvádí např. Aleš Herzog (srov. Aleš HERZOG, Nízkoprahovost a její nároky na pracovníky, in: Teologie a sociální práce - dvacet let dialogu, ed. Michal KAPLÁNEK, Praha: Jabok, 2013, s. 113-119).

6 Srov. Jan PRŮCHA - Eliška WALTEROVÁ - Jiří MAREŠ, Pedagogický slovník, Praha: Portál, 1995, s. 21.
} 
lenky animace $v$ české a slovenské pedagogické literatuře je stručně analyzován také $\checkmark$ našem článku Mnohotvarý fenomén animace. ${ }^{7}$

\section{Animace ve výchově}

Charakteristikou 60. let, které vyvrcholily studentskými a dělnickými boư̌emi v západní Evropě, Woodstockem v Severní Americe a Pražským jarem v Československu, byla ztráta důvěry mládeže $v$ instituce vedené generací tehdejších rodičů; tato krize se týkala jak rodiny a církve, tak i školy a státu. Lidé pracující ve výchově, jako například salesián Riccardo Tonelli, vnímali nutnost začít oslovovat mladé lidi zcela jiným způsobem, než bylo zvykem - škola a rodina ztrácely vliv a tradiční spolky přestaly mladé lidi zajímat. Zato se mládež dávala dohromady sama, spontánně - vytvářela party, které žily zcela jinak než dospělí. Mluvíme o vzniku subkultur. Mario Pollo při svém studiu ve Francii poznal, že se dospělí mohou těmto skupinám přiblížit prostřednictvím animace. Nelíbila se mu však levicová forma sociálně kulturní animace, která mladé lidi neusměrňovala, ale pouze povzbuzovala k boji za "svá práva“" ${ }^{8}$ Jeho názor na výchovu vycházel z židovsko-křest́anské tradice. Název „kulturní animace“ , kterým Pollo označil svoji filosofickou a pedagogickou koncepci, předpokládá, že cílem výchovy je enkulturace, tedy zapojení se do kulturní tradice společnosti, v níž žijeme a jejíž hodnoty (více či méně) přijímáme. Východiskem kulturní animace je antropologie opírající se o myšlenky převážně židovských filosofů 20. století (Cassirer, Wittgenstein, Arendtová, Fraser ad.). Tyto myšlenky jsou pak zasazeny do kontextu křest́anské nauky o milosti. ${ }^{9}$ Pollo vnímá člověka jako bytost $\mathrm{s}$ transcendentálním určením. Proto také animátor $\mathrm{v}$ jeho pojetí musí být člověk duchovně zralý, schopný přiblížit se velikému tajemství člověka a ochotný pomáhat dětem a mladým lidem, aby si vytvořili svou životní vizi (progetto della vita).

Pollo se dívá na člověka sedmerým pohledem: ${ }^{10}$

1) jako na tajemstvi;

2) jako na bytost, která plánuje, vytváří kulturu a vyjadřuje se pomocí symboli;

3) jako na bytost s psychickou zkušenosti;

4) jako na bytost žijící v čase a směřujicí $k$ smrti;

5) jako na bytost, která má své hodnoty a potřeby;

6) jako na svobodného tvora;

7) jako na bytost, která je omezená a přitom touží po nekonečnosti.

Vidí tedy člověka jako (paradoxní) tajemství, v němž je spojena časová i potenciální ohraničenost (omezenost) s touhou po překročení těchto hranic (transcendencí) a se svobodou, která se projevuje prioritou (mravních) hodnot a symbolickými projevy kultury. ${ }^{11}$

Pokud se s kritickým odstupem podíváme na sedm výše uvedených vlastností člověka, které jsou ideovým základem kulturní animace, zjistíme, že k jejich realizaci není nutná konkrétní náboženská víra. Jde spíše o respektování tajemství člověka, jeho života, smrti i jeho naděje na

7 Srov. Anna DUDOVÁ - Michal KAPLÁNEK - Richard MACKŮ, Mnohotvarý fenomén animace, Pedagogická orientace 3/2011, $295-300$.

8 Kritické postřehy Mario Polla k sociálně kulturní animaci můžeme najít v jeho publikacích (napřr. Animazione culturale), biografické souvislosti z jeho života čerpáme z interview, které s ním vedl M. Kaplánek v březnu 2010.

9 „Další ústřední hodnotou animace je gratuità (tedy skutečnost, že podstatné dary dostáváme zdarma, což je základem křest'anské myšlenky milosti, lat. gratia - pozn. M. Kaplánka)... Gratuità, oslava a hra jsou doprovodné hodnoty, které následují po daru (Kristova) kř́iže, př́íkré cesty vykoupení člověka v cizině, v níž dosud žije." (Mario POLLO, Animazione culturale, Roma: LAS, 2004, s. 26.)

10 Podrobněji k tématu viz Michal KAPLÁNEK, Animace, Praha: Portál, 2013, s. 51-60.

11 Pollova koncepce kulturní animace je podrobně popsána v Mario POLLO, Animazione culturale. 
věčnost; respektování člověka jako bytosti náboženské, ale také bytosti slabé a hřišné, která žije v disharmonii současného světa a potřebuje vykoupení. Kulturní animaci tak může uplatňovat i člověk, který se nehlásí k žádné náboženské společnosti. Předpokladem tohoto animačního přístupu je však respekt k člověku jako k tajemství a vyznávání tradičních hodnot, které jsou vlastní evropské kultuře, historicky formované židovsko-křestáanskou tradicí, kterou jsme si v současném politickém diskursu zvykli nazývat „konzervativní“.

\section{Teologické souvislosti kulturní animace}

Právě jsme konstatovali, že kulturní animace sice není metodou, která by byla "vyhrazena“ příslušníkům nějaké církve, přesto však zcela zřetelně a transparentně vychází z židovsko-křest́anské tradice a rozvíjí se v katolickém prostředí. Proto je namístě, abychom se ptali, zda existuje něco jako teologie kulturni animace, případně jaké jsou její základní rysy. Abychom našli aspoň trochu uspokojivou odpověd' na tuto otázku, nemůžeme zůstat pouze u myšlenek zakladatele Mario Polla. Musíme se podívat také do díla salesiánů, kteří tuto metodu dále rozvíjeli a rozvíjí. Jsou to zejména: pastorální teolog Riccardo Tonelli z Itálie, dále Jerome Vallabaraj, mimořádný profesor Papežské salesiánské univerzity v Římě pocházející z Indie a mexický salesián Javier Prieto. Tonelli spoluvytvářel společně s Mario Pollem současný profil kulturní animace a prosazoval ji jako vhodnou metodu pastorace mládeže. Vallabaraj použil kulturní animaci jako východisko pro svou koncepci holistické výchovy a Prieto vytvořil užitečnou pomůcku pro přípravu animátorů, která je dostupná také ve slovenštině. ${ }^{12} \mathrm{~V}$ dílech těchto autorů můžeme najít následující teologické akcenty, které sice nenaznačují žádný ucelený systém teologické reflexe v rámci kulturní animace, ale zcela jistě ovlivnily vývoj animačního přístupu ve výchově:

1) Inkarnace jako teologické východisko vztahu člověka ke světu i k sobě samému Tonelli ve svých vzpomínkách z roku 2009 připomíná tuto volbu následujícími slovy:

„Objevili jsme ... pastorální dimenzi události Vtělení... V Ježíši z Nazareta bylo možné objevit Boha v jeho autenticitě, potkat jej jako totální smysl našeho života ve slabosti a milosti jeho lidství. V něm jsme našli ... vlastní lidství, náš život." Tento „objev“" měl praktické pastorační důsledky, a to ocenění „teologického významu všedního života, této velké svátosti př́tomnosti a setkání s Bohem v Ježíši“ ${ }^{13}$

2) Člověk potřebuje spásu (osvobození)

Život je svátostí tehdy, pokud je autentický a odpovídá Božímu záměru. Ale reálný život je "zamořený hříchem“. Proto Tonelli považuje výchovu za "privilegovaný nástroj, skrze nějž můžeme vrátit každé osobě její životní kvalitu“. Jinými slovy: "potřebujeme spásu“ a "výchova je prostředkem spásy“ ${ }^{14}$ Potřeba spásy je základem animace také u Polla, který si uvědomuje omezenost člověka a jeho hranice.

12 Riccardo TONELLI, Pastorale giovanile e animazione, Torino: Elledici, 1970; Jerome VALLABARAJ, Animating the Young. An Introduction to a Holistic Paradigm of Youth Ministry, Bangalore: Kristu Jyoti Publications, 2005; Javier PRIETO, Smer - človek. Kurz pre animátorov, Bratislava: Don Bosco, 1996.

13 Riccardo TONELLI, Ripensando quarant'anni di servizio alla pastorale giovanile. Intervista a cura di Giancarlo De Nicolò, Note di Pastorale giovanile 5/2009, s. 11-65, citace s. 18.

14 Tamtéž, s. 18 a 20. 
3) Priorita procesu spásy před zprostředkováním spásy

Tonelli ve shodě s Rahnerem rozlišuje mezi procesem spásy a zprostředkováním spásy. Proces spásy je uskutečnění a osobní přijetí spásy. Zprostředkování (mediace) spásy naproti tomu závisí na historické podstatě církve (jako instituce). Proces spásy je osobní svobodný úkon každého člověka. K tomuto osobnímu rozhodnutí dochází prostřednictvím vlastní svobodné komunikace s Bohem v (prostředí) jeho milosti. To nepodléhá církevní správě. Naproti tomu církev má za úkol podporovat, vytuářet príležitosti a podmínky procesu spásy. ${ }^{15}$ Zde je výchozí Rahnerova myšlenka: „Víra a ospravedlnění existují dřive než jejich zprostředkování ze strany církve, ba dokonce ještě před kázáním evangelia." ${ }^{16}$

4) Animace podporuje proces proměny života jako odpověd' na Boží povolání Podle Vallabaraje ${ }^{17}$ znamená animace doprovázení radou a motivací. Toto doprovázení směřuje k pomoci mladým lidem při vytváření jejich životní vize, což lze realizovat jenom $\mathrm{v}$ autentických a svobodných vztazích, v nichž se jednotlivci povzbuzují k tomu, aby rozpoznali své životní poslání. Jedná se tedy o odpověd' člověka na Boží povolání. Chceme-li vidět animaci jako obohacení života, pak ji chápeme jako proces a metodu, která přijímá neustálou proměnlivost života, přičemž pro věřícího člověka je to právě Bůh, který je skrze Ježíše Krista pramenem růstu a rozvoje lidské osoby. Pokud chápeme animaci jako hnutí proměňující život, pak se animace stává strategií, v níž je centrálním prvkem právě život a láska k životu. Cílem této proměny je plnost života, která je pro všechny zjevena Kristem a v Kristu. ${ }^{18}$ Podle Vallabaraje je teologickým základem animace přesvědčení, že „Bůh nás volá v Ježíši Kristu k radikální lásce“. ${ }^{19}$

\section{Profil animátora}

Ve všech pojetích animace je ústřední postavou animátor. V pojetí kulturní animace je animátor člověk, který si zachovává svou vlastní identitu a přitom nabízí kvalitní pedagogické doprovázení.

Animátor je souputníkem skupiny na její cestě. Usměrňuje ji, podněcuje a provází, uvádí do souladu rozdíly mezi jednotlivými členy, probouzí naději a důvěru. Musí být důvěryhodnou osobou, na niž se každý rád obrací. Má být vzorem, protože sám prochází cestou zrání. Proto může být svědkem tradičních hodnot, které jsou součástí jeho identity. ${ }^{20}$

Animátor není čestná funkce ani kariérní stupeň. Jakýkoliv náznak mocenského přístupu nebo manipulace by znamenal nepochopení podstaty animace. Animátor nesmí vnucovat své myšlenky, může je pouze nabízet. ${ }^{21}$

\footnotetext{
15 Srov. Riccardo TONELLI, Pastorale giovanile. Dire la fede in Gesù Cristo nella vita quotidiana. 4. ed. riveduta e aggiornata, Roma: Libreria Ateneo Salesiano, 1987, s. 18.

16 Karl RAHNER a kol., La salvezza nella Chiesa. Strutture fondamentali della mediazione salvifica, Brescia, 1968, s. 14.

17 Zde vycházíme z Vallabarajova díla Animating the Young v jeho italské verzi Jerome VALLABARAJ, Animazione e pastorale giovanile. Un'introduzione al paradigma olistico, Torino: Elledici, 2008.

18 Srov. Jerome VALLABARAJ, Animazione e pastorale giovanile, s. 17.

19 Tamtéž, s. 19.

20 Srov. Javier PRIETO, Smer - človek, s. 208.

21 Srov. tamtéž, s. 209.
} 


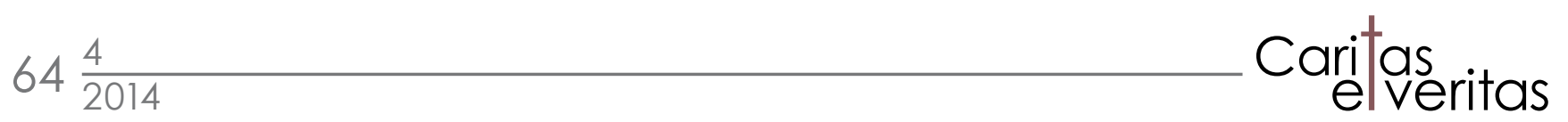

Javier Prieto uvádí šest základních postojů animátora. Prvním z nich je dưvěra v člověka. Animátor věří v každého mladého člověka, především v dobro v něm. Jeho úkolem je pomáhat lidem objevovat jejich vlastní dary (charismata), které jsou často neznámé, skryté, nevyužité, podceňované. Cílem činnosti animátora je, aby jeho svěřenci věřili svým schopnostem včetně schopnosti čelit negativním situacím.

Druhým základním postojem je osvobozující síla výchovné lásky: Aby mladý člověk rozvíjel sílu dobra, potřebuje zažít lásku, která působí osvobození. Tímto postojem Prieto př́mo navazuje na zakladatele salesiánů dona Boska (1815-1888). ${ }^{22}$ Pro salesiánskou výchovu (a tedy i pro animaci v pojetí J. Prieta) je výchova chápána jako cesta evangelizace.

Vychovatel má s mladými lidmi sdílet hlubokou lásku k životu. Pomáhá jim přitom objevovat, pro co mohou žít, prožívat život jako dar, a tak dospět k tomu, aby se ve svém životě dokázali dát do služby druhým.

Dalším prvkem je protagonismus ve výchovném procesu. Pojem „protagonismus“ se používá v italštině a označuje schopnost projevit se, prosadit se a postavit se do čela ostatních, do první linie - v aktivitě, ale také ve službě. Animátor se snaží probudit v mladém člověku chut' růst jako osoba, respektuje jeho svobodu a vlastní kroky. Cílem je, aby se mladý člověk naučil jít svou vlastní cestou a uměl se prosadit. Animátor motivuje a usměrňuje energii mladého člověka a ukazuje mu nové možnosti a perspektivy, provází ho, pomáhá mu najít sebe sama a správně se ocenit. ${ }^{23}$

Tyto postoje by měly mít za následek, že se animátor dokáže aktuálně rozhodnout pro přijetí každého mladého člověka takového, jaký je, pro vytváření výchovného prostředí, které se pro účastníky stane domovem, farností, školou a hřištěm. ${ }^{24}$ Animátor je člověk, který se rozhodl, že bude př́itomný mezi mladými lidmi, bude s nimi sdílet jejich život a současně vydávat svědectví. Jedná se o zvláštní výměnu: Animátor nabízí mladým lidem svoje vnitřní bohatství a současně se od nich učí. Animátor sdílí s mladými lidmi také své postoje, a to formou vlastního př́ikladu a svědectví. ${ }^{25}$

Pro věřícího animátora je skupina mládeže prostorem, v němž prožívá svou zkušenost s Bohem. Proto pro něj není př́ítomnost mezi mladými lidmi nikdy ztrátou času.

\section{Praktické uskutečňování animace v salesiánském prostředí}

Ačkoliv kulturní animace vznikla v italském salesiánském prostředí, bylo by omylem domnívat se, že se stala světově uznávanou metodou práce salesiánů. Jejími tvůrci byli Italové (Pollo a Tonelli), ale mezi salesiány se rozšiřila mnohem více ve španělské jazykové oblasti. Tonelli sám přičítá slabé prosazení této koncepce následujícím důvodům:

\footnotetext{
22 Don Bosco v listu z Říma (1884) povzbuzuje své žáky slovy: „Nestačí, abyste je milovali, chlapci musí cítit, že jsou milováni.“ (Giovanni BOSCO, List sv. Jána Boska z roku 1884. Nestači ich milovat', Rím: SÚSCM, 1984, 36).

23 Srov. Javier PRIETO, Smer - človek, s. 210-211.

24 Don Bosco formuloval poslání oratoře čtyřmi, v jeho době srozumitelnými obrazy: domov znamenal rodinné ovzduší a prostředí důvěry, farnost byla místem socializace a rozvoje duchovního života, škola byla místem, kde se člověk mohl učit věci potřebné pro praktický život a hřiště bylo místem zábavy a spontánní radosti. (Srov. Michal KAPLÁNEK, Výchova v salesiánském duchu, Praha: Portál, 2012, s. 20.)

$25 \mathrm{~V}$ salesiánském prostředí $\mathrm{k}$ těmto postojům neoddělitelně patří také náboženské postoje. Jedná se tak o svědectví víry.
} 
- rozdílnému př́istupu pastorálních teologů a pedagogů na Papežské salesiánské univerzitě;

- pluralitě výchovných modelů;

- pluralitě pohledů na člověka. ${ }^{26}$

Nicméně i v současné revidované př́ručce salesiánské pastorace mládeže vydané Oddělením pastorace mládeže Generálního domu salesiánů v Ř́mě najdeme doporučení vychovávat $v$ animačním stylu. Tento styl je blíže specifikován následujícími vlastnostmi:

- animace uznává schopnost mladých lidí převzít zodpovědnost;

- animace je metoda, která vidí v každém mladém člověku jeho pozitivní vlastnosti, bohatství a vnitřní potenciál a nabízí mu aktivity k jeho rozvoji;

- animace je styl doprovázení mladých lidí radou, motivací, pomocí v každodenním rozvoji skrze vztahy založené na svobodě a vlastním rozhodnutí;

- nejdůležitějším cílem animace je vrátit každému člověku radost z plnosti života a odvahu k naději. ${ }^{27}$

Na tuto stručnou charakteristiku animace navazuje konstatování, že podstatou animačního stylu je osoba animátora, jeho postoje a jednání. Animátor má tedy tyto úkoly:

- podporuje rozvoj skupin mládeže v jejich hledání, reflexi, aktivitách a ideálech;

- pomáhá př́konávat krize ve skupině a vytvářet vztahy mezi členy skupiny;

- vnáší do skupiny prvky kritiky a hlubšího zamyšlení, aby se mladí lidé naučili sdělovat své představy, přání a otázky;

- podporuje komunikaci a spolupráci mezi jednotlivými skupinami v místním salesiánském společenství;

- doprovází jednotlivce v jejich lidském i křestéanském zrání. ${ }^{28}$

Současné postavení animace jakožto metody či přistupu v salesiánských zařízeních můžeme tedy - s určitým zjednodušením - shrnout asi takto: Salesiáni přijali prakticky na celém světě některé prvky kulturní animace, a to zejména empiricko-kritický model plánování, práci se skupinou a péči o všestrannou zralost animátorů. ${ }^{29}$

Pokusy o zavedení animace jako výchovné metody, která se snaží přivést (mladého) člověka $\mathrm{k}$ tomu, aby sám objevoval, co a jak má v životě dělat a jaké názory přijmout za své, se v českém prostředí objevily ojediněle už v první polovině 90 . let 20 . století prostřednictvím časopisu NAIM - časopis pro pastoraci mládeže. ${ }^{30}$ Iniciátorem popularizace animačního př́stupu byl salesián Michael Martinek. Animaci charakterizoval v kontextu pastorace mládeže jako vnitřní proces formace mladého člověka $\mathrm{k}$ osobní zralosti, podněcování vychovatelem na základě osobního vztahu. Animací rozuměl využívání výchovných metod a technik podporujících zmiňovaný proces. Za animátora považoval osobu, která měla aktivizovat svěřené mladé lidi na základě osobního vztahu a používat při své práci animačních metod a technik. Neměl být

\footnotetext{
26 Uvedené informace o Tonelliho postřezích a názorech vycházejí z osobního rozhovoru s R. Tonellim, který realizoval v dubnu 2010 M. Kaplánek.

27 Volně převzato z knihy La Pastorale Giovanile Salesiana. Quadro di Riferimento, Roma: Direzione Generale Opere Don Bosco, 2014 , s. 150.

28 Srov. La Pastorale Giovanile Salesiana, s. 150-151.

29 K jednotlivým prvkům kulturní animace viz Michal KAPLÁNEK, Animace, s. 61-96.

30 NAIM - časopis pro pastoraci mládeže, Praha: Salesiánská provincie Praha.
} 
jen organizátorem a manažerem, ale měl působit na druhé především svým osobním př́ikladem a svým vztahem ke každému jednotlivci. ${ }^{31}$

Vzhledem k tomu, že časopis NAIM vycházel pouze v období let 1994-1997 a byl distribuován pouze v rámci katolické církve, rozvíjel myšlenku kulturní animace pouze omezený okruh lidí. Salesiáni v ČR pracují podle principů kulturní animace spíše implicitně, a to v rámci aktualizace preventionîho systému dona Boska. ${ }^{32}$ Preventivní systém můžeme zjednodušeně charakterizovat několika výraznými prvky, jako jsou: blizkost mladým lidem, citlivost vưči nim, bezpodmínečné prijetí, dialog, víra v dobro v každém člověku, povzbuzeník vlastní iniciativě. Specifické je salesiánské výchovné prostředí, v němž nacházíme autentické mezilidské vztahy, vitalitu a nabídku osobnostního růstu. Prostředí je přitom utvářeno primárně samotnými mladými lidmi.

České i slovenské salesiánské prostředí čerpalo ze stejných teoretických zdrojů, navazovalo tedy na autory italské, španělské a latinskoamerické. ${ }^{33}$ Ze stejných zdrojů pocházejí také stručné informace o animaci, které najdeme v české pedagogické literatuře, např́klad v Pedagogickém slovníku autorské trojice Průcha, Walterová a Mareš z roku $1995 .^{34}$

Animace jako přístup a metoda je známější v slovenském salesiánském prostředí, kde se salesiáni v posledních dvaceti letech snaží rozvíjet problematiku animace také teoreticky. Důvodem k tomu je potřeba přípravy salesiánských dobrovolníků - animátorů.

\section{Slovenská „Škola animácie ${ }^{\Perp}$}

V posledních dvaceti letech etablovali slovenští salesiáni kulturní animaci v slovenském kulturním i společenském prostředí. Od začátku si totiž uvědomovali, že nejde jen o převzetí slova animace, ale o její „výchovné zhodnoceni“" v salesiánském prostředí. Slovenští salesiáni vedli rozsáhlé konzultace se zmíněným mexickým autorem př́ručky pro kurz animátorů Javierem Prietem. Prieto několikrát cestoval na Slovensko a pomáhal formulovat slovenskou verzi příručky pro animátory. Také se zúčastnil prvních kurzů animátorů.

Mezi první školitele a propagátory animace na Slovensku patřil Ladislav Baranyai. Baranyai byl pověřen úkolem uvést animaci do slovenského salesiánského prostředí. Od roku 1994 se mladí lidé ze slovenských salesiánských středisek začali zúčastňovat školení s názvem Škola animace.

Program těchto kurzů probíhal ve třech letech a končil závěrečnými animátorskými zkouškami. Příručky k jednotlivým tématům jsou rozděleny na tři části: pracovní, programovou a studijní. V pracovní části jsou otázky a prostor pro osobní záznamy účastníků kurzu. V programové části je podrobně popsaný celý průběh školení (pro školitele). V studijní části se nacházejí informace, které prohlubují téma a jsou inspirací pro další podrobnější studium. ${ }^{35}$

Tyto materiály pomáhají animátorům nejen při výchově, ale jsou také podnětem pro jejich

31 Srov. Michael MARTINEK, Animátor skupiny, NAIM - časopis pro pastoraci mládeže 2/94, s. 7-9; Michael MARTINEK, Animace, NAIM časopis pro pastoraci mládeže 1/94, s. 11-13.

32 Srov. Michal KAPLÁNEK, Výchova v salesiánském duchu, Praha: Portál, 2012, s. 86-88.

33 Juan E. VECCHI, Pastorale giovanile. Una sfida per la comunità ecclesiale, Torino: LDC, 1992; Riccardo TONELLI, Pastorale e animazione, Roma, 1990; Alfonso FRANCIA, Curso para jóvenes cristianos animadores de grupos. Dinámica de grupos, Madrid: Editorial CCS, 1989.

34 Srov. Jan PRŮCHA - Eliška WALTEROVÁ - Jiří MAREŠ, Pedagogický slovník, s. 21.

35 Srov. Ladislav BARANYAI, Príprava stretnutí a itinerárov, Bratislava: DOMKA, 2008. 
osobnostní rozvoj. Témata pomáhají animátorům zvyšovat svoji úroveň a zdokonalovat práci se skupinou. Skrze ně poznávají hlouběji situaci současné mládeže a specifika prostředí, v němž žijí.

V současnosti se formace animátorů realizuje v rámci rozsáhlého projektu Cesty zrenia. ${ }^{36}$ Jedná se o výchovný projekt propracovaný pro jednotlivé věkové skupiny, které jsou homogenně rozdělené (nekoedukované). Až skupiny ve věku 18-25 let jsou společné - a zde je zpracována problematika vztahů muže a ženy a jejich zrání. Projekt počítá s vrstevnickou skupinou a její dynamikou. Důležitou roli hraje animátor, který musí splňovat speciální podmínky. Tyto podmínky odpovídají požadavkům Maria Polla na animátora (osobnostní zralost a schopnost autentických vztahů). ${ }^{37}$

Animátoři ze salesiánských středisek jsou posíláni na školení, kde se jednak seznamují s celým projektem, ale současně se věnují zejména té věkové skupině, s níž sami pracují. Tomu napomáhá opět pečlivě zpracovaný pracovní materiál. ${ }^{38}$

\section{Možnost uplatnění slovenského modelu v českém prostř̌edí}

Společné pro českou a slovenskou salesiánskou výchovnou praxi je orientace na volný čas dětí a mládeže. Rozdíly jsou v cílových skupinách, s nimiž salesiáni pracují. Zatímco animátoři slovenských salesiánských středisek jsou vesměs věřící mladí lidé, kteří vytváří křest́anské společenství, v České republice je situace jiná. Zde se musí počítat s tím, že významnou cílovou skupinou práce salesiánů jsou právě mladí lidé, kteří jsou sociálně znevýhodnění. ${ }^{39}$ Otázkou je, jak získat pro takovou cílovou skupinu animátory, kteří by odpovídali vysokým osobnostním požadavkům, které formulují tvůrci koncepce kulturní animace. Další otázkou je, kdo vlastně takovému požadavku vyhovuje.

Bezpodmínečným předpokladem je lidská zralost. Jestliže mluvíme o lidské zralosti, kterou má vychovatel mít, máme tím na mysli právě schopnost vnímat člověka v jeho celistvosti, tedy v kontextu jeho fyzického, psychického, sociálního a duchovního života. Současně musí animátor umět povzbuzovat k vytváření vlastní životní vize, která umožní mladému člověku najít perspektivu svého života (a to i tehdy, když patří do reálně znevýhodněné skupiny, např. nezaměstnaných).

Tak jako v každé profesi, i u pedagogů platí, že pro konkrétní činnosti musí mít člověk vlohy. Neznamená to, že by bez vrozených dispozic nemohl tuto práci vykonávat, ale musí na svém profesním i osobnostním vývoji o to více pracovat.

Výše zmíněné nároky na animátora, jak je formuluje Javier Prieto, ${ }^{40}$ se mohou zdát v našem prostředí nedosažitelné nebo dokonce nepřiměřené. V praxi se ovšem nepočítá $s$ tím, že každý dosáhne maxima svých možností. Ideál „zralého animátora" má být především apelem na to, aby každý pedagog zvažoval, zda v tomto směru nemá rezervy. Jde o to, aby pedagogové volného času nabízeli možnosti a učili mladé lidi zacházet se svým životem. Je požadavkem doby, aby pedagogové volného času „pomáhali dětem a mladým lidem při vytváření jejich

\footnotetext{
36 Internetové stránky projektu (online), dostupné na http://www.cestyzrenia.domka.sk.

37 Srov. Michal KAPLÁNEK, Animace, s. 38-39.

38 Cesty zrenia - dievčatá, Bratislava: DOMKA, 2010.

39 Srov. Michal KAPLÁNEK, Výchova v salesiánském duchu, s. 63-67.

40 Srov. Javier PRIETO, Smer - človek, s. 208-211.
} 
životní vize“, jak to formulovali účastníci 10. konference o výchově a volném čase, která se konala v Praze v červnu $2014 .{ }^{41}$

Je nutné zmínit, že existují určité předpoklady, aby mohl být animační přístup uplatněn. Animace tak, jak ji popisujeme, vychází z židovsko-křest’anských tradic. Animátor se sice považuje za reprezentanta tradičních hodnot. Může však nabízet pouze to, co sám zná a uznává. Je-li animátor původem z jiného než křest'anského kulturního prostředí, musíme počítat s tím, že může $v$ některých případech dávat přednost jiným hodnotám, než jsou ty, které jsme popsali výše.

Animátor by měl být vnitřně zralý, aby mohl nabízet svůj pohled ostatním, a také proto, aby různost názorů lidí kolem něj zcela nerozbourala jeho vlastní vnitřní integritu. Je však ku prospěchu, pokud i animátor umí hledat - dává tím osobní příklad všem, na které se snaží působit. Společné „tápání v životě“ skupinu motivuje, zatímco jedinec - pokud by byl ponechán sám sobě - by se mohl utápět v beznaději.

Animátor musí dobře znát nástroje hledání. Měl by být průvodcem, který naučí skupinu pracovat s buzolou a poté ji vyšle $\mathrm{k}$ individuálnímu prozkoumávání terénu. Animátor by tedy neměl být „vůdcem“, který vždy ví, kam jít. Měl by spíše pomáhat mladým lidem, aby svoji životní cestu sami našli.

\section{Kulturní animace - fillosofická východiska a praktické využití}

Abstrakt Autorský tým z Katedry pedagogiky Teologické fakulty Jihočeské univerzity v Českých Budějovicích navazuje na společný článek Mnohotvarý fenomén animace z roku 2011 a na monografii $M$. Kaplánka Animace z r. 2013. Zatímco ve svých dosavadních publikacích se autoři snažli spiše upřesnit pojem „animace" a prezentovat jednotlivé směry animace, tato studie pojednává především o tzv. kulturní animaci, která se stala výchovnou metodou, a o jejím využití v pedagogické praxi. Príkladem využití animace je program formace animátorů, který uskutečňuji salesiáni na Slovensku. Tento program se realizuje v rámci katolické církve, a proto i tento text výrazněji zdưrazňuje teologická východiska animace.

Klíčová slova animace; kulturní animace; výchova; pedagogika volného času; Salesiáni Dona Boska; Mario Pollo; Riccardo Tonelli

\section{Cultural Animation - Philosophical Grounding and Practical Use}

Abstract The team of authors from the Department of Pedagogy at the Faculty of Theology, University of South Bohemia in České Budějovice, follow up on their article The Pluriform Phenomenon of Animation from 2011 and M. Kaplánek's monograph Animation from 2013. While in their publications so far the authors strove rather to specify the concept of "animation" and present the individual lines of animation, this study deals primarily with so-called cultural animation which has become an educational method, and with its use in pedagogical practice. An example of using animation is the programme for animator formation employed by Salesians in Slovakia. This programme is realized within the Catholic Church, which is why this text emphasizes the theological foundations of animation.

Keywords animation; cultural animation; education; leisure time education; Salesians of Don Bosco; Mario Pollo; Riccardo Tonelli 